\title{
developing children's reasoning and inquiry, concept analysis, and meaning- making skills through the community of inquiry
}

\author{
abigail thea canuto ${ }^{1}$ \\ university of the philippines - philippines
}

abstract

This paper presents the results of a research done to investigate the effectiveness of Philosophy for Children (P4C), a pedagogy employing philosophical dialogue in a community of inquiry, in a Philippine primary school. Quantitative analysis of critical thinking skills identified by Sharp and Splitter (1995) as (1) reasoning; (2) concept analysis; and (3) meaning-making revealed that there was a considerable increase in the frequency of the children's use of such critical thinking skills over the course of fifteen (15) sessions of dialogical inquiry. Moreover, qualitative analysis of excerpts from the dialogue transcripts accounted for the refinement of the children's use of the critical thinking skills. This pioneering work thus calls for further research that will implement $\mathrm{P} 4 \mathrm{C}$ in other grade levels and to explore other indicators of development in children's thinking. Further, it recommends that primary schools adopt P4C in Philippine basic education curriculum and that teacher education institutions provide teacher training and include $\mathrm{P} 4 \mathrm{C}$ for pre-service training.

keywords: critical thinking; assessment; philosophical dialogue; community of inquiry; philosophy for children.

\section{desenvolver o raciocínio e a investigação de crianças, a análise de conceitos e as habilidades de criação de significado por meio da comunidade de investigação}

resumo

Este artigo apresenta os resultados de uma pesquisa feita com vistas à investigar a eficácia da Filosofia para Crianças (FpC), uma pedagogia que emprega o diálogo filosófico em uma comunidade de investigação, em uma escola primária das Filipinas. A análise quantitativa das habilidades de pensamento crítico identificadas por Sharp e Splitter (1995) como (1) raciocínio; (2) análise conceitual e (3) criação de significado revelaram que houve um aumento considerável na frequência do uso de tais habilidades de pensamento crítico pelas crianças através do curso de quinze (15) sessões de investigação dialogada. Além disso, a análise quantitativa dos excertos dos diálogos transcritos colaboraram ao refinamento do uso pelas crianças das habilidades de pensamento crítico. Assim, este estudo pioneiro clama por uma investigação adicional, que implemente a FpC em outros níveis de classe e que explore outros indicadores de desenvolvimento no pensamento infantil. Ademais, ele recomenda que as escolas primárias adotem a FpC no currículo da educação básica das Filipinas, e que os instituições de formação continuada ofereçam treinamento aos professores e incluam a FpC também para o treinamento de formação dos professores.

\footnotetext{
${ }^{1}$ E-mail: abigailthea1@gmail.com
} 
developing children's reasoning and inquiry, concept analysis, and meaning-making skills through the community of inquiry

palavras-chave: pensamento crítico; avaliação; diálogo filosófico; comunidade de investigação; filosofia para crianças.

\section{desarrollar el razonamiento y la investigación de los niños, el análisis de conceptos y las habilidades de creación de significados a través de la comunidad de investigación.}

resumen

Este artículo presenta los resultados de una investigación realizada en una escuela primaria de Filipinas, con el objetivo de estudiar la eficacia de la Filosofía para Niños y Niñas (FpN), pedagogía que emplea el diálogo filosófico en una comunidad de investigación. El análisis cualitativo de las habilidades de pensamiento crítico identificadas por Sharp y Splitter (1995): (1) raciocinio, (2) análisis conceptual y (3) creación de significado, revelaron que hubo un aumento considerable en la frecuencia del uso de tales habilidades de pensamiento crítico por parte de los niños y niñas a través del curso de quince (15) sesiones de investigación. Además de eso, el análisis cuantitativo de fragmentos de los diálogos transcritos colaboraron con el refinamiento del uso por parte de niños y niñas de las habilidades de pensamiento crítico. Así, este estudio pionero clama por una investigación adicional, que implemente la FpN en otros niveles y que explore otros indicadores de desarrollo en el pensamiento infantil. Además, recomienda que las escuelas primarias adopten la $\mathrm{FpN}$ en el currículo de la educación básica de Filipinas y que las instituciones de formación continuada ofrezcan capacitación a los profesores y profesoras e incluyan la $\mathrm{FpN}$ también en la formación de los profesores y profesoras

palabras clave: pensamiento crítico; evaluación; diálogo filosófico; comunidad de investigación; filosofía para niños y niñas. 
developing children's reasoning and inquiry, concept analysis, and meaning-making skills through the community of inquiry

\section{introduction}

Many educators testify to the apparent ability of young students to display inquisitiveness, creativity, and critical thinking as observed in classroom discourse as well as in spontaneous conversations with and among them. As such, teachers generally deem it a mistake not to capitalize on such abilities and direct them for success in academic subjects. Others add that children need to develop control and mastery of their thinking skills so that they can effectively understand and utilize new information independently (AHMAD ASSAF, 2009). Furthermore, many educators believe that if children will be trained in the craft of disciplined and critical thinking, they will more likely be productive citizens of their society both in their work and in helping solve social problems by acting on intelligent judgments (FISHER, 2003 in AHMAD ASSAF, 2009).

To develop the kind of thinking that is disciplined and critical, children need to be exposed to a variety of factors. Most educators agree that the kind of environment most conducive for children to develop their thinking skills is one where there is a caring adult who assists in the students' thinking processes and who models thinking behaviors and attitudes such as curiosity, open-mindedness and logicality (FISHER, 2005). Likewise, it is ideal that there are ample opportunities for accomplishing various tasks with peers and where there are challenging activities that demand the use of higher-order thinking skills. Therefore, in school settings where rote learning and teacher-centered instruction are the trend, children's minds are viewed as underused (WILSON, 2000).

A general framework which most thinking skills programs rest upon is presented by 
developing children's reasoning and inquiry, concept analysis, and meaning-making skills through the community of inquiry

McGuinness (1999), which she derived from data gathered in a review and evaluation of research on thinking skills and related areas carried out by The Department of Education and Employment in the United Kingdom. The framework includes

the need to make thinking skills explicit in a curriculum; teaching thinking through a form of coaching; taking a metacognitive perspective; collaborative learning; creating dispositions and habits of good thinking; generalizing the framework beyond a narrow focus on skills to include thinking curricula, thinking classrooms and thinking schools (MCGUINNESS, 1999, p.1).

Nevertheless, there are still specific thinking skills programs and each has its own theoretical underpinnings and thus, its own targeted outcomes and manner of assessment. For instance, some of the programs examine and accelerate certain thinking processes while others look at manifestations of specific thinking skills in specific contexts (such as in classroom discussions and in subject areas like reading, science, and mathematics). Still a number of others focus on the ideas and judgments generated by use of logical thinking and reflective thinking (such as in philosophical dialogues). Accordingly, hypotheses about how people can most efficiently develop thinking skills differ across and within the disciplines of psychology, education, and philosophy.

\section{perspectives on critical thinking}

\section{the cognitive psychological perspective}

Two paradigms are commonly associated with the psychological approach: the behaviorist tradition and experimental research paradigm on one hand and cognitive psychology on the other. While the former is more concerned with "how people actually think versus how they could or should think under ideal conditions" (STERNBERG, 1986 in LAI, 2011, p.7), the latter deals more with "the types of actions or behaviors critical thinkers can do... (which) ...includes a list of skills or procedures performed by critical thinkers" (LEWIS; SMITH, 1993 in LAI, 2011, p.7). This 
paradigm is more inclined to examine the mental processes that take place in a person's mind in the course of reconciling a problematic event or idea. Because of this, educators such as Facione (1990, mentioned in LAI, 2011) and Van Gelder (2005, in LAI, 2011, p. 7) warn against "confusing the activity of critical thinking with its component skills", and argue that "critical thinking is more than simply the sum of its parts". Furthermore, Bailin (2002, cited in LAI, 2011, p.7) argues that "it is possible to simply 'go through the motions,' or proceed through the 'steps' of critical thinking without actually engaging in critical thought".

\section{the educational perspective}

One of the most influential members of the educational approach is Benjamin Bloom, who with his associates, formulated Bloom's Taxonomy of Educational Objectives used by many teachers in teaching and evaluating higher-order thinking. Thinking skills here are organized in a hierarchy, with "comprehension" at the bottom and "evaluation" at the top. Specifically, "the three highest levels (analysis, synthesis, and evaluation) are said to represent critical thinking" (KENNEDY et al., 1991 as mentioned in LAI, 2011, p. 8). However, while such manner of organizing skills presents clear-cut descriptions of learning objectives and expected outcomes, some educators protest against the very idea of a hierarchy of thinking skills.

Lipman (2003), for instance, claims that generally speaking, it is improper to view a taxonomy of thinking skills as hierarchical since in the first place, thinking skills are not supposed to be compared with each other because there is no issue of which is 'better' a skill. Rather, it is the context that determines the appropriateness or superiority of a given skill. Furthermore, he observes that when these skills are "isolated in categories in a taxonomy[...] they appear inert and sterile. But when they are at work in the process of inquiry, the can function dynamically - and critically" (LIPMAN, 2003, p.214). Finally, Lipman (2003, p. 40) attributes the widely accepted view of a developmentally hierarchical view of critical thinking to the penetration of 
developing children's reasoning and inquiry, concept analysis, and meaning-making skills through the community of inquiry

Bloom's concepts to the "Piagetian empire in education... (where) ...the hierarchy was to be understood as a theory of developmental stages".

\section{the philosophical approach}

Perhaps what sets the philosophical approach apart from the two other perspectives regarding the notion of critical thinking is the fact that it focuses primarily on a person's "qualities and characteristics", and with the "behaviors or actions" seen as mere reflections of such qualities and characteristics (LEWIS; SMITH, 1993, THAYER-BACON, 2000 as cited in LAI, 2011, p.5). In addition, Facione (1990 in LAI, 2011, p. 5) quotes the American Philosophical Association's (APA) following descriptions of a critical thinker: "inquisitive in nature, open-minded, flexible, fairminded, has a desire to be well-informed, understands diverse viewpoints, and is willing to both suspend judgment and to consider other perspectives", thereby placing highest emphasis on the qualities of thinking. The philosophical perspective thus construes critical thinking as not merely an aggregate of skills that one can utilize but, more importantly, as a process of understanding and learning, the quality of which is made exemplary by certain attitudes and values such as those identified by the APA. Nevertheless, some critics would claim that the philosophical perspective may not be efficiently able to explain how people actually think.

Many teachers, especially those that employ inquiry-based discussions in the classroom, may claim that they are already teaching critical thinking in their classrooms. Evidently, such a claim is made with an underlying assumption of what critical thinking is. If the perspective of the philosophical approach is taken and there is an acknowledgement that promoting thinking, reasoning and judgment-making with regard to values and fostering better understanding of concepts (GIORDMAINA, 2005) are the primary thrusts of a thinking skills program, there is a very good chance that there is still something lacking in the curriculum. 
In this context, philosophy is conceived as something children naturally and competently do even at a young age (CROWHURST, 1988; DELANOY, 1997; MATTHEWS, 1976; STEIN; TRABASSO, 1982 as mentioned in GLINA, 2009; RONDHUIS, 2005; UNESCO, 2007; 2009) and the sort of philosophy that would suit the early grades classroom is hence practical philosophy. Academic philosophy, on the other hand, is concerned mainly with ideas of well-known philosophers and getting students to learn about them, such as how it is usually done in high school or college philosophy classes. Thus, philosophy in children's classrooms would be more like what it was for Socrates: "neither an acquisition nor a profession but a way of life" (LIPMAN, 1988, p.12 cited in MURRIS, 2000). Such a way of life is recommended to start early because it provides a unique opportunity for children to get more meaning from their experiences. This, according to Juuso (2007, p. 66), makes philosophy "useful for all children" and a "viable and critical subject for a young person's intellectual diet" (DELANOY, 1997, p.3).

Given all these, practicing philosophical thinking in the early grades is a worthwhile opportunity to explore because it will increase the chances of preserving children's natural curiosity and wonder as well as their predilection to ask existential questions, which according to Fisher (2006), is likely to decline as they get older. Furthermore, Lipman (2003) argues that to allow the habit of sound thinking among young children does not only serve to remedy difficulties in thinking but also to prevent the tendency of unreasonableness.

\section{philosophy for children ( $p 4 c)$}

Matthew Lipman believed that the best solution to college students' reasoning deficiencies was for logic and philosophy be taught much earlier in the school, but not in the way that it is usually taught to college students (LIPMAN, 1976; 2003). Instead, he believes that a democratic environment characterized by trust and mutual respect where children could habitually practice their thinking with each other is 
developing children's reasoning and inquiry, concept analysis, and meaning-making skills through the community of inquiry

necessary. Such an environment would be what the psychologist Lev Vygotsky describes as a setting where children interact and communicate with others who can assist in the progress of their current level of knowledge and understanding (SUTCLIFFE, 2001; VYGOTSKY, 1962 in WILSON, 2000). Charles Peirce refers to this setting as a community of inquiry which Juuso (2007, p. 68) further depicts as "a reflective, participatory community that is committed to self-corrective inquiry in its problems and choices". The pedagogy that Lipman conceived of, where children as young as preschool can engage in philosophical dialogue in a community of inquiry is hence called Philosophy for Children (P4C).

The usual P4C session would start with a stimulus for inquiry which is often a storybook embedded with philosophical concepts. This is then followed by a few minutes of thinking time to allow the children to come up with questions about concepts in the story that they find contestable and problematic. Among these questions, one will be chosen by the children as the starting point of the inquiry, after which the dialogue will then follow. The direction of the dialogue will rely largely upon the children, except when the teacher finds that they have reached a dead end or that the children's comments are no longer relevant. The teacher can then direct the children's attention to the next question or bring into focus the last relevant point made. At the end of the dialogue, the community will review the points for convergence and discuss those that remain open for further inquiry (DANIEL, 2005; FISHER, 2006; HAYNES, 2007; HAYNES; MURRIS, 2001).

The P4C method has been proven effective to enhance cognitive, social, and oral language skills among children by researchers from around the world (CAGLA, 2011; DANIEL, 2005, DANIEL, PETTIER; AURIAC-SLUSARCZYK, 2011; IAPC, 2003; ROBERTS, 2006). The contribution of this paper consisted in the very first investigation of $\mathrm{P} \mathrm{C}^{\prime}$ 's effectiveness in a Philippine primary school. First, it took note of the frequency of occurrences of the children's critical thinking skills and second, it 
determined whether the ideas generated by the children through the use of these skills were, in fact, better and not merely different or original.

\section{critical thinking skills in philosophical dialogue}

As implied, the critical thinking skills expected to be manifested in a philosophical dialogue reflect the philosophical perspective's definition of critical thinking. An example of a comprehensive list of such skills is Sharp and Splitter's (1995) Marks of a Philosophical Discussion. Note that while Sharp and Splitter do not refer to the following as "skills", the author found that not only are these marks synonymous to critical thinking skills identified by many other theorists and thinkers, but as a whole, they also encapsulate the dispositional component of critical thinking, thereby serving as a framework for the qualitative analysis of the data gathered:

Reasoning and inquiry. These skills are not exclusive to philosophy. In this context, what makes them manifestations of critical thinking in the philosophical approach is the reflective and self-conscious attitude that students develop as they reason and inquire. As such, in evaluating the transcripts, it was not enough to merely identify the occurrences of these skills but also to determine whether the participants were using their ability with vigilance to evaluate how well these skills are being used by themselves as well as by other participants of the community of inquiry. Thus, the transcripts provided evidence, for instance, not only of whether the participants are giving and asking reasons, but also if they have a good understanding of what "good reasons" are.

The skills of reasoning and inquiry enumerated by Sharp and Splitter (1995, p. pp.128-133) are

giving reasons; distinguishing good reasons from bad ones; constructing inferences and evaluating arguments; induction; identifying, questioning, and justifying assumptions; recognizing contradictions; detecting fallacious reasoning; striving for consistency; making distinctions and connections; asking questions and problem seeking; making predictions, formulating and testing hypotheses; offering examples and counterexamples; formulating and using 
developing children's reasoning and inquiry, concept analysis, and meaning-making skills through the community of inquiry

criteria; detecting vagueness and ambiguity; asking for evidence; taking all relevant considerations into account; asking for evidence.

Analysis of concepts. Analyzing philosophical concepts involves asking about the meanings that people assign to such concepts and setting their boundaries based on human experience. These concepts are contestable or problematic and are common to everyone's experience such as fairness, truth, goodness, friendship, beauty, time, rules, reality, rights, duty, freedom, identity, art, knowledge, and many others.

Improved understandings are arrived at through negotiation of personal meanings through dialogue. Hence, delving deeper into the meanings of concepts is different from asking how, in fact, the world functions according to these concepts (e.g., 'Does every story have a beginning?' vs. 'What is the beginning of the story?').

Meaning-making. Making meanings allow for bridging the gap between what is currently understood and what is not. These are instances when participants apply, reflect, and evaluate the processes of reasoning and inquiry. These are manifested by the questions and statements that attempt to clarify vague, puzzling, confusing and ambiguous concepts (e.g., 'Are you saying that something can't be good in both senses at once?').

\section{methodology}

Lipman (2003, p. 162) characterizes thinking skills as a "catchall phrase" which suggests that a list of such skills may be endless and that the skills may overlap with one another. Considering this, while this paper utilized Sharp and Splitter's (1995) Marks of a Philosophical Discussion in order to identify the typical skills that occur in philosophical dialogue, it needs to be noted that the design of the study is mainly qualitative and it aimed to go beyond the mere identification and frequency count of such skills. Specifically, it made use of descriptive analysis in examining the patterns of interaction of the participants in the philosophical dialogues and to monitor shifts from simpler to more complex, disciplined, and critical thinking. Ultimately, these 
patterns reflected whether progress in the critical thinking skills of the participants after fifteen (15) sessions can be observed.

The research locale was a private primary school located in Daet, Camarines Norte in the Bicol Region. The town, which is the capital of the province, is situated 340 kilometers south of Metro Manila. The study utilized convenience sampling. There was one heterogeneous Grade Two class of 18 students, 10 of which were girls and 8 were boys. The students came from middle-income families. Their predominant language was Filipino.

One instrument was used in this study. The Marks of a Philosophical Discussion enumerated by Sharp and Splitter (1995) was used as reference in determining the number of occurrences of critical thinking skills and sub-skills in each dialogue as well as in confirming whether there was increase in the frequency of their use in the course of 15 sessions. The analysis likewise relied heavily on the context of the dialogues to give a clear description of the manner by which the skills were employed by the children.

The following is a list of the critical thinking skills and sub-skills enumerated by Sharp and Splitter (1995) that was used as guide in this study. It may be noted that the way Sharp and Splitter described them is consistent with Lipman's (2003) characterization of thinking skills. The coding of sub-skills was designed by the author for clear categorization and identification in the frequency count.

1) reasoning and inquiry $(R I)$ - $\left(R I_{1}\right.$ - giving reasons; $\mathrm{RI}_{2}$ - constructing inference \& evaluating judgments; $\mathrm{RI}_{3}$ - identifying, questioning \& justifying assumptions; $\mathrm{RI}_{4}$ detecting fallacious reasoning; $\mathrm{RI}_{5}$ - making distinctions/connections; $\mathrm{RI}_{6}$ - making predictions, formulating \& testing hypotheses; $\mathrm{RI}_{7}$ - detecting vagueness \& ambiguity; $\mathrm{RI}_{8}$ - taking all relevant considerations into account; $\mathrm{RI}_{9}$ - distinguishing good reasons from bad ones; $\mathrm{RI}_{10}$ - induction; $\mathrm{RI}_{11}$ - recognizing contradictions; $\mathrm{RI}_{12}$ striving for consistency; $\mathrm{RI}_{13}$ - asking questions \& problem seeking; $\mathrm{RI}_{14}$ - offering 
developing children's reasoning and inquiry, concept analysis, and meaning-making skills through the community of inquiry

examples \& counter-examples; $\mathrm{RI}_{15}$ - formulating \& using criteria; $\mathrm{RI}_{16}$ - asking for evidence; $\mathrm{RI}_{17}$ - correcting one's own thinking)

2) analysis of philosophical concepts (PC)

3) meaning- making $(M M)$ - $\left(\mathrm{MM}_{1}\right.$ - application of, reflection on, evaluation of the processes of reasoning and inquiry; $\mathrm{MM}_{2}$ - references to general, contestable concepts; $\mathrm{MM}_{3}$ - questions and statements that make for meaning)

The occurrences of these skills were located in the transcribed dialogues and tallied in frequency tables. Where some of the sub-skills were found to be overlapping with others, the sub-skills were counted one by one and the main skill was counted as one (e.g., $\mathrm{RI}_{6}, 13,15=1 \mathrm{RI}$ skill; $1 \mathrm{RI}_{6} ; 1 \mathrm{RI}_{13} ; 1 \mathrm{RI} \mathrm{I}_{15}$ ). The occurrences of each skill and RI and MM sub-skills were analyzed to determine whether there was increase in the frequency of their use. Excerpts from the transcriptions also provided evidence for the quality of how these skills were being used.

\section{results and discussion}

As shown in the frequency table below, there was a considerable increase in the frequency of the use of the three main critical thinking skills, which are the following: reasoning and inquiry (RI), analysis of concepts (PC) and meaning-making (MM) from Session 5 onwards. Particularly, the most frequently occurring RI subskills were $\underline{\mathrm{RI}_{6}}$ (making predictions, formulating \& testing hypotheses), $\underline{\mathrm{RI}} \underline{13}_{3}$ (asking questions \& problem seeking) \& $\underline{\mathrm{R}}_{14}$ (offering examples \& counter-examples) while the most frequently observed MM sub-skill was $\underline{\mathrm{MM}}_{3}$ (questions and statements that make for meaning). 
Table 1. Frequency of Critical Thinking Skills in Sessions 1-15

\begin{tabular}{ccccc}
\hline$\underline{\text { SESSION }}$ & $\begin{array}{c}\text { Reasoning \& } \\
\text { Inquiry } \\
(\boldsymbol{R I})\end{array}$ & $\begin{array}{c}\text { Analysis of } \\
\text { Philosophical } \\
\text { Concepts } \\
(\boldsymbol{P C})\end{array}$ & $\begin{array}{c}\text { Meaning- } \\
\text { Making } \\
(\mathbf{M M})\end{array}$ & $\underline{\text { TOTAL }}$ \\
\hline$\underline{\mathbf{1}}$ & 59 & 4 & 3 & 66 \\
\hline$\underline{\mathbf{2}}$ & 74 & 1 & 1 & 76 \\
\hline$\underline{\mathbf{3}}$ & 54 & 2 & 1 & 57 \\
\hline$\underline{\mathbf{4}}$ & 79 & 2 & 3 & 84 \\
\hline$\underline{\mathbf{5}}$ & 75 & 22 & 10 & 107 \\
\hline$\underline{\mathbf{6}}$ & 211 & 12 & 25 & 248 \\
\hline$\underline{\mathbf{7}}$ & 134 & 34 & 13 & 181 \\
\hline$\underline{\mathbf{8}}$ & 148 & 5 & 10 & 163 \\
\hline$\underline{\mathbf{9}}$ & 169 & 22 & 28 & 219 \\
\hline$\underline{\mathbf{1 0}}$ & 164 & 7 & 23 & 194 \\
\hline$\underline{\mathbf{1 1}}$ & 199 & 24 & 29 & 252 \\
\hline$\underline{\mathbf{1 2}}$ & 79 & 23 & 14 & 116 \\
\hline$\underline{\mathbf{1 3}}$ & 158 & 49 & 38 & 245 \\
\hline$\underline{\mathbf{1 4}}$ & 128 & 65 & 30 & 223 \\
\hline$\underline{\mathbf{5}}$ & 202 & 36 & 47 & 285 \\
\hline
\end{tabular}


Table 2. Frequency of Reasoning E Inquiry Sub-skills in Sessions 1-15

\begin{tabular}{|c|c|c|c|c|c|c|c|c|c|c|c|c|c|c|c|c|c|c|}
\hline SESSION & $\mathrm{RI}_{1}$ & $\mathrm{RI}_{2}$ & $\mathrm{RI}_{3}$ & $\mathrm{RI}_{4}$ & $\mathrm{RI}_{5}$ & $\mathrm{RI}_{6}$ & $\mathrm{RI}_{7}$ & $\mathrm{RI}_{8}$ & $\mathrm{RI}_{9}$ & $\mathrm{RI}_{10}$ & $\mathrm{RI}_{11}$ & $\mathrm{RI}_{12}$ & $\mathrm{RI}_{13}$ & $\mathrm{RI}_{14}$ & $\mathrm{RI}_{15}$ & $\mathrm{RI}_{16}$ & $\mathrm{RI}_{17}$ & TOTAL \\
\hline$\underline{1}$ & 5 & 2 & 0 & 1 & 6 & 18 & 1 & 0 & 0 & 0 & 1 & 0 & 7 & 28 & 1 & 0 & 0 & 70 \\
\hline$\underline{2}$ & 18 & 4 & 0 & 0 & 8 & 14 & 0 & 0 & 0 & 3 & 0 & 0 & 4 & 11 & 33 & 0 & 1 & 96 \\
\hline$\underline{3}$ & 8 & 9 & 0 & 0 & 7 & 24 & 0 & 2 & 0 & 8 & 0 & 0 & 1 & 13 & 0 & 0 & 1 & 73 \\
\hline$\underline{4}$ & 4 & 10 & 0 & 1 & 3 & 22 & 0 & 1 & 0 & 4 & 0 & 1 & 2 & 36 & 6 & 0 & 0 & 90 \\
\hline$\underline{5}$ & 5 & 1 & 2 & 2 & 6 & 41 & 0 & 13 & 3 & 3 & 0 & 0 & 21 & 8 & 0 & 0 & 2 & 107 \\
\hline$\underline{6}$ & 6 & 4 & 0 & 12 & 18 & 92 & 0 & 7 & 1 & 2 & 1 & 1 & 88 & 17 & 12 & 0 & 3 & 264 \\
\hline$\underline{7}$ & 1 & 8 & 0 & 6 & 6 & 56 & 1 & 8 & 2 & 5 & 1 & 0 & 51 & 20 & 2 & 0 & 1 & 168 \\
\hline 8 & 5 & 4 & 0 & 4 & 18 & 74 & 3 & 4 & 1 & 3 & 1 & 2 & 45 & 18 & 8 & 0 & 2 & 192 \\
\hline$\underline{9}$ & 0 & 18 & 0 & 4 & 16 & 77 & 0 & 11 & 6 & 10 & 3 & 0 & 57 & 20 & 5 & 0 & 3 & 230 \\
\hline$\underline{10}$ & 8 & 16 & 0 & 15 & 20 & 75 & 0 & 2 & 18 & 1 & 1 & 4 & 62 & 11 & 2 & 0 & 4 & 239 \\
\hline$\overline{11}$ & 6 & 29 & 3 & 17 & 32 & 87 & 2 & 1 & 1 & 13 & 0 & 0 & 48 & 33 & 8 & 0 & 1 & 281 \\
\hline 12 & 2 & 16 & 0 & 0 & 17 & 34 & 0 & 0 & 1 & 7 & 1 & 1 & 8 & 24 & 1 & 0 & 2 & 114 \\
\hline$\underline{13}$ & 11 & 9 & 0 & 24 & 15 & 81 & 0 & 2 & 1 & 3 & 10 & 5 & 45 & 11 & 1 & 0 & 6 & 224 \\
\hline 14 & 2 & 14 & 1 & 9 & 21 & 71 & 1 & 3 & 4 & 2 & 5 & 4 & 16 & 6 & 5 & 2 & 7 & 173 \\
\hline$\underline{15}$ & 11 & 9 & 0 & 20 & 24 & 99 & 0 & 6 & 8 & 1 & 9 & 5 & 27 & 41 & 6 & 3 & 1 & 270 \\
\hline TOTAL & 79 & 153 & 6 & 115 & 217 & 865 & 8 & 60 & 46 & 65 & 33 & 23 & 482 & 297 & 90 & 5 & 34 & \\
\hline
\end{tabular}


Table 3. Frequency of Meaning-making Sub-skills in Sessions 1-15

\begin{tabular}{ccccc}
\hline SESSION & $\begin{array}{c}\text { application } \\
\text { of, reflection } \\
\text { on, } \\
\text { evaluation of } \\
\text { the processes } \\
\text { of reasoning } \\
\text { and inquiry }\end{array}$ & $\begin{array}{c}\text { references to } \\
\text { general, } \\
\text { contestable } \\
\text { concepts }\end{array}$ & $\begin{array}{c}\text { questions and } \\
\text { statements } \\
\text { that make for } \\
\text { meaning }\end{array}$ & TOTAL \\
\hline$\underline{\mathbf{1}}$ & 0 & 0 & 2 & \\
\hline$\underline{\mathbf{2}}$ & 1 & 0 & 0 & 2 \\
\hline$\underline{\mathbf{3}}$ & 0 & 0 & 1 & 1 \\
\hline$\underline{\mathbf{5}}$ & 1 & 1 & 1 & 1 \\
\hline$\underline{\mathbf{6}}$ & 4 & 0 & 6 & 3 \\
\hline$\underline{\mathbf{7}}$ & 10 & 0 & 11 & 10 \\
\hline$\underline{\mathbf{8}}$ & 4 & 0 & 9 & 21 \\
\hline$\underline{\mathbf{9}}$ & 1 & 0 & 9 & 13 \\
\hline$\underline{\mathbf{1 0}}$ & 3 & 6 & 19 & 10 \\
\hline$\underline{\mathbf{1 1}}$ & 2 & 0 & 21 & 28 \\
\hline$\underline{\mathbf{1 2}}$ & 6 & 0 & 23 & 23 \\
\hline$\underline{\mathbf{1 3}}$ & 3 & 5 & 11 & 19 \\
\hline$\underline{\mathbf{1 4}}$ & 13 & 1 & 24 & 38 \\
\hline$\underline{\mathbf{1 5}}$ & 8 & 0 & 22 & 30 \\
\hline$\underline{\mathbf{T O T A L}}$ & 6 & 7 & 38 & 51 \\
\hline & 62 & 20 & 197 & \\
\hline
\end{tabular}

Sessions 1 and 2 are characterized by RI skills that were largely unsupported and unelaborated. They were primarily used to answer the teacher's probing questions and were not spontaneously offered to enrich the exchange among the children. As such, such skills were used in an isolated manner where the students are not yet affecting each other's ideas. The dialogues were hence considered lacking in philosophical quality. 
developing children's reasoning and inquiry, concept analysis, and meaning-making skills through the community of inquiry

Figure 1. Excerpt from the dialogue in Session 2 (On making friends)

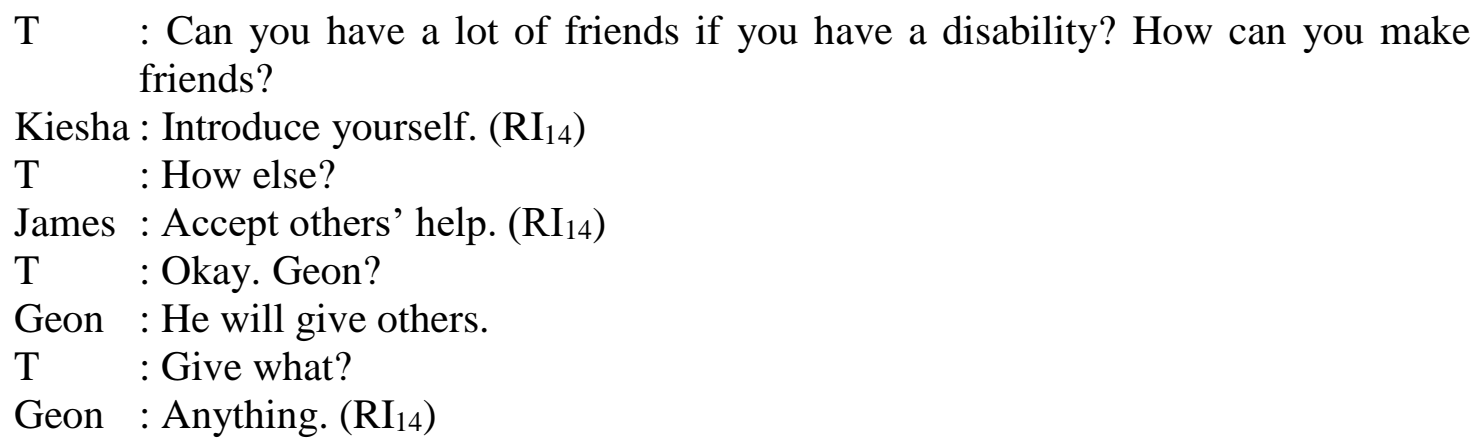

By Sessions 3 and 4, the children were able to formulate their conclusions by inferring and making generalizations from reasons given throughout the dialogue. It was also apparent that the children were generally limited by their concrete experiences and coming up with examples of hypothetical situations was a necessary step for them in constructing hypotheses and in making distinctions and connections. This is a manifestation of the children's current cognitive states which could be somewhere between the preoperational and concrete operational (GORDON; BROWNE, 2004).

Figure 2. Excerpt from the dialogue in Session 4 (On forgiving others)

$\mathrm{T} \quad$ : Why does he remain to be your friend [even when he did something wrong towards you]?

Brian : Because he will say sorry. $\left(\mathrm{RI}_{1}\right)$

$\mathrm{T} \quad$ : What if he doesn't say sorry? $\left(\mathrm{RI}_{13}\right)$

James : If he doesn't say sorry, they will become enemies. $\left(\mathrm{RI}_{2}, 10\right)$

On the other hand, Sessions 5 and 6 marked improvements in the children's use of RI and PC skills. Specifically, personal anecdotes were used more to evaluate each other's reasoning than to merely talk about their personal experiences. The children also started probing ideas further by hypothesizing about the consequences of their classmates' suggestions and using them to formulate counter-examples and counter-arguments. However, there was still a tendency for the children to address 
problems with further problems, reflecting their lack of ability to decide which issue to grapple with first.

Figure 3. Excerpt from the dialogue in Session 6 (On arrogance)

\begin{tabular}{|c|c|}
\hline $\mathrm{T}$ & $\begin{array}{l}\text { : Aside from what Kiesha said, what else could be a reason for people } \\
\text { to be arrogant or to act arrogantly? }\end{array}$ \\
\hline KC/Dave & : So that they could tease others. $\left(\mathrm{RI}_{6}\right)$ \\
\hline Kym & $\begin{array}{l}\text { : What if, Teacher, he only learned arrogance from his mother? }\left(\mathrm{RI}_{5} \text {, }\right. \\
13, \mathrm{PC})\end{array}$ \\
\hline $\mathrm{KC}$ & : What if he didn't learn the attitude from his mother? $\left(\mathrm{RI}_{13}, \mathrm{PC}\right)$ \\
\hline James & $\begin{array}{l}\text { : Maybe from a sibling. The sibling is arrogant then the other sibling } \\
\left.\text { imitated him. Mothers don't act... ...don't teach... fighting. (RI } \mathrm{I}_{6}, \mathrm{PC}\right)\end{array}$ \\
\hline Kуm & : What if the mother learned the attitude from her mother? $\left(\mathrm{RI}_{13}, \mathrm{PC}\right)$ \\
\hline $\mathrm{KC}$ & : What if the mother imitated the grandmother? $\left(\mathrm{RI}_{13}, \mathrm{PC}\right)$ \\
\hline Kiesha & $\begin{array}{l}\text { : When the mother tells the child to do something wrong, the child } \\
\text { should not do it if he knows that it is wrong. }\left(\mathrm{RI}_{6}, 14, \mathrm{PC}\right)\end{array}$ \\
\hline Niña & : What if the parent taught a wrong behavior to the child? $\left(\mathrm{RI}_{13}, \mathrm{PC}\right)$ \\
\hline Kiesha & $\begin{array}{l}\text { : Don't do that because the child might get into an accident and he } \\
\text { knows it's wrong anyway, so he shouldn't do it in the first place. (RI } 6 \text { ) }\end{array}$ \\
\hline
\end{tabular}

The largely spontaneous manner by which the children test the plausibility of each other's suggestions as soon as they are uttered by their classmates in Sessions 7 and 8 shows how they are growing to be more sensitive to the weaknesses of the reasons given by their peers. Moreover, while there were unresolved issues at the end of the dialogue, the children were still able to identify the strongest arguments and considered them as conclusions. This provides evidence that the community was starting to think in a more cohesive, unified manner (DANIEL, 2005; DANIEL et al., 2011). 
developing children's reasoning and inquiry, concept analysis, and meaning-making skills through the community of inquiry

Figure 4. Excerpt from the dialogue in Session 8 (On job competence)

$\mathrm{T} \quad$ : Kiesha, you said the manager will decide who to hire based on who is competent in the job. How would he determine that? $\left(\mathrm{RI}_{6},{ }_{13}, \mathrm{PC}\right)$

Kiesha : Let him take a test. $\left(\mathrm{RI}_{6}\right)$

James : What if the one you decided to hire isn't persevering? $\left(\mathrm{RI}_{13}\right)$

Ninay : Then fire him. $\left(\mathrm{RI}_{6}\right)$

Kiesha : Observe. There's a test to determine if someone is persevering or not. (RI $\mathrm{I}_{6}$, 15)

Ninay : What if he only tricked you into thinking that he is persevering? $\left(\mathrm{RI}_{6}, 13\right)$

James : Yes, what if he tricked you into thinking that? $\left(\mathrm{RI}_{6}, 13\right)$

Ninay : Then fire him and replace him with a persevering one. $\left(\mathrm{RI}_{6}\right)$

James : The one who is persevering, Teacher, one who could be the boss! $\left(\mathrm{RI}_{6}, 15\right)$

Kiesha: You should really determine during the training if he's really persevering. $\left(\mathrm{RI}_{5}, 6,15\right)$

In Session 9, the children has learned to look at the problem from different angles and even predict where one was going with his statement even if he has not yet finished his sentence. In forming new conclusions, they were also able to infer from given examples and use induction as well as hypothesize possible consequences. Ultimately, by following the logic of the dialogue, they were able to choose the most sensible action to avoid unfavorable outcomes.

Figure 5. Excerpt from the dialogue in Session 9 (On inheriting attitudes from parents)

Dessa : Teacher, the child should inherit attitudes from his parents. $\left(\mathrm{RI}_{6}, \mathrm{PC}\right)$

Gian : What if he inherited his mother's indolence? $\left(\mathrm{RI}_{13}\right)$

Kiesha: Gian, maybe if the mother had changed her attitude, the child would change, too. $\left(\mathrm{RI}_{5}, 6, \mathrm{PC}\right)$

Gian : What if the mother's attitude did not change? $\left(\mathrm{RI}_{13}\right)$

Kiesha: What if the father is kind? $\left(\mathrm{RI}_{13}\right)$

Gian : What if the attitudes are inherited from the grandmother? $\left(\mathrm{RI}_{13}\right)$

Dessa : What if the child inherited the attitudes and the child became indolent? $\left(\mathrm{RI}_{13}\right)$

Ninay : What if attitudes were inherited from his aunt? $\left(\mathrm{RI}_{13}\right)$

James : What if attitudes were inherited from his uncle? $\left(\mathrm{RI}_{13}\right)$

Gian : What if all family members are indolent? $\left(\mathrm{RI}_{8}, 13, \mathrm{PC}\right)$

Kiesha : The child knows that being indolent is wrong, [such as to] depend too much on others. $\left(\mathrm{RI}_{6}, \mathrm{PC}\right)$ Because his teachers teach him to be industrious. $\left(\mathrm{RI}_{6}\right)$

Gian : What if even the teacher is indolent? $\left(\mathrm{RI}_{13}\right)$

Ninay : They already know that it's wrong; they are old enough. $\left(\mathrm{RI}_{4}, 6\right)$

Gian : But what if all people are indolent? $\left(\mathrm{RI}_{13}, \mathrm{PC}\right)$ 
The children's tendency to have difficulty divorcing their thinking from what they are experiencing in real life was apparent in Session 11. This is likely because of their current cognitive phase (HAMERS; OVERTOON 1997, cited in Assaf, 2009). As such, they found it difficult to suppose hypothetical examples when they regarded it as absurd in real life. Nevertheless, it was notable how even if most of the children made the same inferences, hypotheses, and induction, they were not done by simply repeating what the others said.

Figure 6. Excerpt from the dialogue in Session 11 (On why men can't wear skirts)

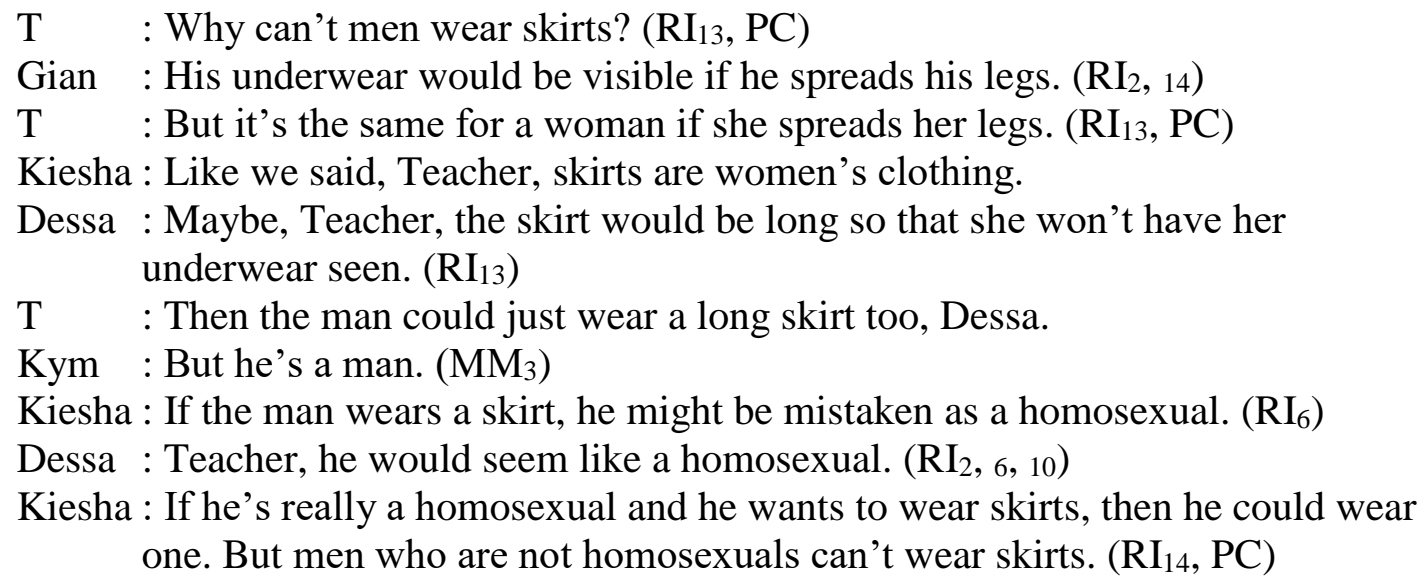

The ability to focus on the flow of the dialogue and to be critical of each other's utterances was further evidenced in Sessions 12 and 13. In Session 12, instances of self-correction showed that the children were able to choose sounder arguments and change their perspectives depending on how the dialogue progressed. On the other hand, Session 13 showed not only how the children were thinking together but also how they were making their suggestions intersubjective, such as when they cite their classmates' arguments in investigating a certain issue. The children's growing ability to analyze and define philosophical concepts by making connections among the arguments offered by various participants in the community plainly illustrates critical and philosophical thinking (DANIEL, 2005; DANIEL et al., 2011). 
developing children's reasoning and inquiry, concept analysis, and meaning-making skills through the community of inquiry

Figure 7. Excerpt from the dialogue in Session 13 (On hasty generalizations)

Dessa : What if all the pets die in the hospital? $\left(\mathrm{RI}_{13}\right)$

James : That's impossible, Dessa! $\left(\mathrm{RI}_{4}\right)$

Kiesha : Because, Dessa, the pet doctor takes care of the pets. $\left(\mathrm{RI}_{5}, 6, \mathrm{PC}\right)$

Dessa : It could be that you think (that he doesn't hurt them), (but) he may actually be poisoning them. $\left(\mathrm{RI}_{6}, \mathrm{PC}\right)$

James : Maybe, Dessa, what you're saying is that all dogs in the hospital die? $\left(\mathrm{MM}_{3}\right)$

Kiesha : Not all pet doctors poison the dogs in the hospital. $\left(\mathrm{RI}_{4}, 5,6, \mathrm{PC}\right)$

James : That's why they are called 'pet doctors'. $\left(\mathrm{RI}_{4},{ }_{5}, \mathrm{PC}, \mathrm{MM}_{2}\right)$

Celine : Then all the pets in there should have died. $\left(\mathrm{RI}_{2}, 4,6,10,11\right)$

Kiesha: The doctor knows how to cure the dogs because he studied about it. (RI 6 , PC)

Celine : The doctor knows what sort of medicine to use... $\left(\mathrm{RI}_{6}\right)$

Kiesha: That's why he was able to establish a business because he knows about the medicines. $\left(\mathrm{RI}_{2}, 6, \mathrm{PC}\right)$

James : Dessa, it's absurd that, for instance, one of the foods was poisoned [and then] all the dogs would die. $\left(\mathrm{RI}_{4}, 11,12\right)$

Kym : Yes, only one ate it then all of them would die? $\left(\mathrm{RI}_{4}, 11,12\right)$

The children continued to display willingness to change their minds in light of stronger arguments in Session 14. It is remarkable how they were able to make an objective conclusion that was against what they initially wanted after having taken all considerations into account and which allowed them to converge on a higher good. This ability to weigh out their options based on the logicality of arguments presented serves testament to the children's growing trust, confidence and autonomy in the process of dialogue (DANIEL, 2005; DANIEL et al., 2011). 
Figure 8. Excerpt from the dialogue in Session 14 (On growing old and dying)

Kiesha: I wish, Teacher, when I grow old, I wouldn't be like this (demonstrates wrinkling of face). Because, Teacher, that would be ugly. (RI5)

Dessa : Indeed. I wish I wouldn't have a mirror so I won't see it.

$\mathrm{T} \quad$ : Is it possible that you wouldn't get wrinkled when you get old? $\left(\mathrm{RI}_{13}, \mathrm{PC}\right)$

Gian : *shakes head* Because when you're old, your skin wouldn't be smooth anymore. $\left(\mathrm{RI}_{6}\right)$

Kiesha : It's okay, Teacher, if it's just a few wrinkles. As long as not a lot of wrinkles can be seen. $\left(\mathrm{RI}_{5}\right)$

Ninay : How is that even possible? $\left(\mathrm{RI}_{7}\right)$

$\mathrm{T}$ : Which do you prefer, Kiesha? You'll die at 60 when you have fewer wrinkles, or at 90 , which is longer, but you'll have more wrinkles? $\left(\mathrm{RI}_{13}, \mathrm{PC}\right)$

Geon : I prefer to die at 90 !

Kiesha: At 90, Teacher, but...

Geon : You're being too particular about wrinkles. $\left(\mathrm{RI}_{2}, \mathrm{PC}\right)$

Kiesha : I'd want to have wrinkles, Teacher, but not too much. (RI5)

T : But when you're 90 years old, Kiesha, you won't be able to help it. You would really have lots of wrinkles then. $\left(\mathrm{RI}_{12}\right)$

Kiesha : As long as I live a long life, Teacher, then it's okay. $\left(\mathrm{RI}_{15}, 17\right)$

Geon : Let it be if you get ugly, Kiesha. $\left(\mathrm{RI}_{9}, \mathrm{PC}\right)$

James : When you're already in heaven, you won't have wrinkles there. $\left(\mathrm{RI}_{6}, \mathrm{PC}\right)$

Kiesha : It's okay, that I would get wrinkled when I grow old, as long as I live a long life. $\left(\mathrm{RI}_{15}\right)$

Dessa : Teacher, the face isn't (so) important. James is right, when you're already in heaven, it would all be gone. Just don't mind it too much. (RI $6,9, \mathrm{PC})$

Kiesha : Yes, I think I'd also want to have wrinkles, even if it's a lot, it's okay... ...just as long as I live a long life. $\left(\mathrm{RI}_{15}\right)$

Session 15 is particularly remarkable because it provides evidence of the children's ability to formulate their own theory of "good", which surpasses the limitation of the preoperational and concrete operational stage of cognitive development. This serves proof not only of how the children's critical thinking skills progressed over 15 sessions, but also how essential philosophical dialogue was in this development as it clearly provided a venue to explore questions that are existential in nature. Apparently, the deep understanding and reasoning that they call for can be achieved only through inquiry into the meanings and nature of concepts (HAYNES, 2007). 
developing children's reasoning and inquiry, concept analysis, and meaning-making skills through the community of inquiry

Figure 9. Excerpt from the dialogue in Session 15 (On being law-abiding)

T : Okay. Now, let's go back to Kiesha and Kym's question. Their question is: 'Why are there people who don't abide by the law even when they know it's wrong to do so? Even if they know they could be punished?' ( $\left.\mathrm{RI}_{13}, \mathrm{PC}\right)$

Kiesha : Maybe he's just following others who don't want to abide by the law even if he knows himself that it's wrong. ( $\left.\mathrm{RI}_{6}, 14, \mathrm{PC}\right)$

Dessa : Kiesha, what if for instance, he stole some money because he really needs it? $\left(\mathrm{RI}_{14}\right)$

Kiesha : That not allowed, Dessa. If he knows it's wrong, he won't do it because of the fact that it's wrong. If it's right, he'll do it because it's the right thing to do. He won't be caught by the police. $\left(\mathrm{RI}_{5}, 6, \mathrm{PC}\right)$

James : You will be caught, like when you steal from a grocery store or a supermarket. There are CCTVs installed there, you will easily be caught. $\left(\mathrm{RI}_{14}\right)$

Dessa : Because your face will be identified. $\left(\mathrm{RI}_{2}\right)$

$\mathrm{T}$ : What if there's no CCTV or policemen? Is it okay (to break the law)? (RI ${ }_{5}$, 13)

Celine : (No) Because, Teacher, they know that it's wrong. $\left(\mathrm{RI}_{6}, \mathrm{PC}\right)$

Kiesha : No. Because, Teacher, the store owner might suddenly see... $\left(\mathrm{RI}_{14}\right)$

$\mathrm{T} \quad$ : What if, Kiesha, no one will see you? Is it okay to steal? You won't be caught anyway. ( $\left.\mathrm{RI}_{13}, \mathrm{PC}\right)$

Celine : Teacher, don't do that because it's wrong. $\left(\mathrm{RI}_{1}\right)$

Kiesha : *shakes head* Because it's wrong. $\left(\mathrm{RI}_{1}, \mathrm{PC}\right)$

Celine : It's really wrong. (PC)

Liana : Because he knows it's wrong. $\left(\mathrm{RI}_{1}, 6, \mathrm{PC}\right)$

Dessa : Teacher, it's not allowed to steal and when you get jailed, you'll just find that it's difficult to live there. $\left(\mathrm{RI}_{6},{ }_{14}\right)$

James : They should remember that this is why there's a law that we should follow. $\left(\mathrm{RI}_{15}, \mathrm{PC}, \mathrm{MM}_{2}\right)$

Clearly, it can be observed from the frequency count of the critical thinking skills that there was a steady increase in the children's use of such skills from Session 5 onwards. As previously mentioned, this study also aimed to account for the development in the quality of the children's critical thinking and it did so by carefully characterizing the kinds of questions and reasons that the participants generated across the 15 sessions. Conscientiously taking into account Lipman's notion of critical thinking as context-based, this paper provided the excerpts where the critical 
thinking skills were employed in coordination with each other. Furthermore, ensuring that its analysis is in line with the philosophical perspective of critical thinking, this paper was careful to establish the dispositional component of the participants' critical thinking which can be specifically attributed to the intellectual habits practiced in the community of inquiry.

\section{conclusions and recommendations}

Evidence from the frequency tables and descriptive analyses of the transcribed dialogues confirms Lipman's theory that philosophical dialogue in a community of inquiry enhances children's critical thinking skills and allows them to think reflectively, ask probing questions, and make reasonable judgments. While it was found that the children had a natural ability to ask 'What if?' even prior to exposure to the P4C method, it was found that participating in dialogical inquiry particularly refined their skills in formulating and testing hypotheses, in problem seeking and in giving examples and counter-examples, such as when they provided clearer ones when their previous examples were misunderstood by others or were lacking in logical strength. The children likewise exhibited growth in the use of RI skills as they progressed from highly intuitive reasoning to one that was based upon logic, such as when they corrected their initial notions when their peers offered stronger arguments or pointed out weaknesses in their statements.

The skill of analyzing philosophical concepts (PC) and meaning-making (MM) was also observed to have become internalized by the children, such as when they built upon one another's ideas in order to establish criteria in determining how a resolution applies, which is deemed highly characteristic of critical thinking specific in philosophical dialogues. As a result, the children were able to widen whole group's perspective about a particular concept by making connections between the arguments and analyses made by their peers. 
developing children's reasoning and inquiry, concept analysis, and meaning-making skills through the community of inquiry

Finally, as it was apparent that the children's improved ability to think critically can be attributed to their interdependence on each other, it is concluded that the Vygotskyan sociocultural foundations of the community of inquiry played a major role in allowing the children to reach their Zone of Proximal Development as regards their understanding of particular concepts.

The kind of development in the children's critical thinking observed in this study thereby establishes that while critical thinking does involve a multitude of skills, educators should not be quick to presume that when students acquire critical thinking skills, it may then be claimed that intellectual dispositions such as inquisitiveness, open-mindedness, and willingness to self-correct are automatically being cultivated along with it. As Lipman (2003, p. 172) argues, "if we want children to grow up to be reflective adults, we should encourage them to be reflective children $[\ldots]$ " (and) "[...] if thinking skills are to be taught, they should be taught in the context of ongoing communities of inquiry". It is important to emphasize that communities of inquiry must be ongoing so that it can be ensured that the habits of asking questions, challenging ideas, expressing justifications, and taking responsibility for one's judgments are exercised alongside the acquisition of critical thinking skills. Indeed, "it is the job of a thinking skills program to develop these habits and dispositions, and not just the skills themselves" (LIPMAN, 2003, p.172).

Hence, considering the exclusive thinking skills and dispositions developed by the method of $\mathrm{P} 4 \mathrm{C}$, it is endorsed that educational institutions initiate an inspection into the unique benefits of philosophical inquiry to young children and, ultimately, consider either acquiring the method of philosophical inquiry as a discrete subject area or integrating it with other subjects such as English, Filipino, Art, Social Studies, as well as in Science and Mathematics. Likewise, teacher education institutions are called to provide more venues for teacher training in facilitating philosophical dialogues and to include $\mathrm{P} 4 \mathrm{C}$ in the curriculum for pre-service training. 
Finally, since a wide debate on the assessment of progress in philosophical dialogues persists among educators, researchers and advocates of $\mathrm{P} 4 \mathrm{C}$, future research may look into more comprehensive and holistic criteria for evaluating the development of thinking skills and ideas generated in philosophical dialogues. It may also help shed further light on the general process of enhancing thinking skills in dialogical inquiry to look into other indicators of development in thinking such as in children's non-verbal behaviors while they engage in philosophical dialogue.

\section{references}

AHMAD ASSAF, M. Teaching and thinking. A literature review of the teaching of thinking skills. Abu Dhabi Education Council, 2009.

CAGLA, G. International conference on education and educational psychology (ICEEPSY 2010) --- Philosophy in the early years. Procedia Social and Behavioral Sciences, 2011, 12, 501-511. DANIEL, M.-F. Learning philosophical dialogue in preschool. A Paper presented in $2 \mathrm{e}$ Global Conference, 2005.

DANIEL, M.-F. PETTIER, C.-J.\& Auriac-Slusarczyk, E. The incidence of philosophy on discursive language competence in four-year-old pupils. Creative Education, 2011, 2(3), 296304.

DELANOY, M. Teaching philosophical thinking through children's literature: creative applications for dialogue and story. Submitted to Educational Resources Information Center (ERIC), 1997. FISHER, A. 'Thinking skills' and admission to higher education. A discussion paper commissioned by the University of Cambridge Local Examinations Syndicate, 2005. FISHER, R. Talking to think: why children need philosophical discussion. in D. Jones and P. Hodson (eds.) Unlocking speaking and listening. London: David Fulton, 2006.

GIORDMAINA, J. Communities of conversation. in Dialogue on Dialogue, A Resource Book for The 'Developing Dialogue Through Philosophical Enquiry' Course for Teachers. Produced under the EU Socrates Scheme by the Menon group, 2005.

GLINA, M. Democracy as morality: using philosophical dialogue to cultivate safe learning communities. Analytic Teaching and Philosophical Praxis, 2009, 29(1), 31-38.

GORDON, A.; BROWNE, K. Beginnings and beyond: foundations in early childhood education. 6th ed. NY: Delmar, 2004.

HAYNES, J. Thinking together: enjoying dialogue with children. in D. Hayes (ed.) Joyful teaching and learning in the primary school. Glasgow, Great Britain: Learning Matters Ltd, 2007. HAYNES, J.; MURRIS, K. Opening up space for children's thinking and dialogue. Paper presented at the Annual Meeting of the United Kingdom Reading Association in Canterbury, Kent, UK, 2001.

INSTITUTE FOR THE ADVANCEMENT OF PHILOSOPHY FOR CHILDREN. What is 'Philosophy for Children'?, 2003. Retrieved on July 6, 2015 from http://cehs.montclair.edu/academic/iapc/whatis.shtml\ 
developing children's reasoning and inquiry, concept analysis, and meaning-making skills through the community of inquiry

JUUSO, H. Child, philosophy and education --- discussing the intellectual sources of philosophy for children. Published doctoral dissertation: University of Utrecht. Oulu, Finland: Oulu University Press, 2007.

LAI, E. Critical thinking: a literature review (research report). 2011. Retrieved on February 12, 2016 from http://www.pearsonassessments.com/hai/images/tmrs/CriticalThinkingReviewFINAL.pd $\mathrm{f}$

LIPMAN, M. Philosophy for children. Metaphilosophy, 1976, 7(1), 17-39.

LIPMAN, M. Thinking in education (2nd ed.). New York, NY: Cambridge University Press, 2003. MATTHEWS, G. On talking philosophy with children. Royal Institute of Philosophy Lectures, $1976,10,46-62$.

MCGUINNESS, C. From thinking skills to thinking classrooms: A review and evaluation of approaches for developing pupils' thinking. Research report RR115. Nottingham: DfEE Publications, 1999.

MURRIS, K. Can children do philosophy? Journal of Philosophy of Education, 2000, 34(2), 261279.

ROBERTS, A. F. The effects of a teacher development programme based on Philosophy for Children. Unpublished master's thesis: University of Western Cape, 2006.

RONDHUIS, T. Philosophical talent. Unpublished doctoral dissertation: University of Utrecht, 2005.

SHARP, A.M.; SPLITTER, L.J. Teaching for better thinking: the classroom community of inquiry. Melbourne: The Australian Council for Educational Research Ltd, 1995.

SUTCLIFFE, R. Philosophy for Children --- teaching thinking, 2001. Retrieved on December 7, 2015 from http:/ / www.teachthinking.com

WILSON, V. Can thinking skills be taught?. A discussion paper presented at the Scottish

Council for Research in Education, 28-42, 2000

UNESCO. Philosophy a school of freedom - teaching philosophy and learning to philosophize: status and prospects. Paris, France: United Nations Educational, Scientific and Cultural Organization Social and Human Sciences Sector, 2007.

UNESCO. Teaching philosophy in Asia and the Pacific. Paris, France: United Nations

Educational, Scientific and Cultural Organization, 2009.

received in: 01.04.2017

approved in: 19.01.2018 